Supplement of Biogeosciences, 16, 3621-3635, 2019

https://doi.org/10.5194/bg-16-3621-2019-supplement

(C) Author(s) 2019. This work is distributed under

the Creative Commons Attribution 4.0 License.

(c) (1)

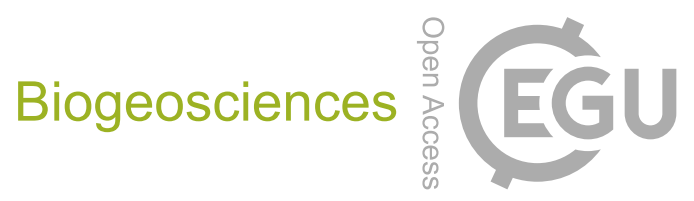

Supplement of

\title{
Isotopic fractionation of carbon during uptake by phytoplankton across the South Atlantic subtropical convergence
}

Robyn E. Tuerena et al.

Correspondence to: Robyn E. Tuerena (r.tuerena@ed.ac.uk)

The copyright of individual parts of the supplement might differ from the CC BY 4.0 License. 


\section{Supplementary Material}

\section{$\underline{\text { Size class calculations }}$}

The size classes of phytoplankton were calculated using seven diagnostic pigments which are used as biomarkers of specific taxa as calculated from the HPLC data (see methods). The taxa can be used to estimate the proportion of micro-, nano- and pico-phytoplankton (equations 1-4).

$$
\begin{aligned}
& w D P=1.4(\text { fucoxanthin })+1.41(\text { peridinin })+0.6(\text { alloxanthin })+0.35\left({ }^{\prime} 19-B F\right)+1.27\left(19^{\prime}-H F\right)+ \\
& 0.86(\text { zeaxanthin })+1.01(\text { Chl } b+\text { divinyl }- \text { Chl } b) \\
& \text { fmicro }=(1.41(\text { fucoxanthin })+1.41(\text { peridinin })) / w D P \\
& \text { fnano }=\left(1.41(\text { alloxanthin })+0.35\left(19^{\prime}-B F\right)+1.27\left(19^{\prime}-H F\right)\right) / w D P \\
& \text { fpico }=(0.86(\text { zeaxanthin })+1.01(\text { Chlb }+ \text { divinyl }- \text { Chlb })) / w D P
\end{aligned}
$$

The coefficients, derived from multiple regression analysis of chla and the concentration of the most dominant diagnostic pigments, are broadly related to taxa. This method contains caveats, which include:

- $\quad$ pigments are shared across taxa

- cells adjust their pigments ratios in response to light/nutrient stress

- this proxy was derived for a global study to estimate phytoplankton groups from satellites, therefore, the shifts in size structure as you go from the gyres (Prochlorococcus dominated) to an upwelling system (diatom dominated) are nicely captured but the high latitudes may be misrepresented.

In this dataset we transition from gyre-like to mesotrophic conditions, which we believe should be accounted for relatively accurately with this method. Bricaud et al., (2004) also found a good correspondence to the optical properties of phytoplankton, which can be viewed as an independent proxy of cell size. 
$\underline{\text { Rau et al., } 1996 \text { model }}$

On initial experiments for this work, it was found that $\left[\mathrm{CO}_{2(\mathrm{aq})}\right]$ alone was not a suitable determinant of the $\delta^{13} \mathrm{C}$ of POC in surface waters across the SSTC, therefore the importance of other factors needed to be examined. The Rau model is used as the intracellular carbon concentration is dependent on $\left[\mathrm{CO}_{2(\mathrm{aq})}\right]$, cell radius, cell growth rate, cell membrane permeability to $\left[\mathrm{CO}_{2(\mathrm{aq})}\right]$ and temperature. This therefore allows the importance of these variables to be tested.

Here we include the baseline values within the model:

\begin{tabular}{|c|c|c|}
\hline Parameter & Value or calculation & Units \\
\hline specific growth rate $(\mu)$ & 1.1 & $\mathrm{~d}^{-1}$ \\
\hline instantaneous cell doubling time $\left(\mu_{\mathrm{i}}\right)$ & $\mu / 24 / 60 / 60$ & $\mathrm{~d}^{-1}$ \\
\hline $\begin{array}{l}\text { Enzymatic isotope fractionation } \\
\text { associated with intracellular fixation ( } \varepsilon f)\end{array}$ & 25 & $\%$ \\
\hline $\begin{array}{l}\text { diffusive isotope fractionation of } \mathrm{CO} 2 \mathrm{aq} \\
\text { in seawater }(\varepsilon \mathrm{d})\end{array}$ & 0.7 & $\%$ \\
\hline Cell wall permeability to $\mathrm{CO}_{2}(\mathrm{P})$ & $1 \mathrm{e}^{-4}$ & $\mathrm{~m} \mathrm{~s}^{-1}$ \\
\hline Surface area equivalent cell radius $(\mathrm{r})$ & 10 & $\mu \mathrm{m}$ \\
\hline Cell volume (V) & $\left(4 \pi r^{3}\right) / 3$ & $\mu \mathrm{m}^{3}$ \\
\hline Carbon content per cell $(\gamma \mathrm{c})$ & $0.00000000000003154 * V^{0.758}$ & $\mathrm{~mol} \mathrm{C}$ \\
\hline $\mathrm{CO}_{2}$ uptake rate per cell $\left(\mathrm{Q}_{\mathrm{s}}\right)$ & $\left(\gamma c^{*} \mu_{\mathrm{i}}\right) /\left(4^{*}\left(\mathrm{pi}^{*}\left(\mathrm{r}^{2}\right)\right)\right)$ & $\mathrm{mol} \mathrm{C} \mathrm{m}^{-2} \mathrm{~s}^{-1}$ \\
\hline $\begin{array}{l}\text { Temperature -sensitive diffusivity of } \\
\mathrm{CO}_{\text {2aq }} \text { in seawater }\left(\mathrm{D}_{\mathrm{T}}\right)\end{array}$ & $0.000005019 * \exp ^{\left(-\left(19510 /\left(8.3143^{*}(\operatorname{temp}+273.15)\right)\right)\right)}$ & $\mathrm{m}^{2} \mathrm{~s}^{-1}$ \\
\hline$\delta^{13} \mathrm{C}$ of $\mathrm{CO}_{2}\left(\delta^{13} \mathrm{C}_{\mathrm{CO} 2}\right)$ & $1.3+23.644-9701.5 /($ temp+273.15) & $\%$ \\
\hline $\begin{array}{l}\delta^{13} \mathrm{C} \text { of particulate organic carbon }\left(\delta^{13} \mathrm{C}-\right. \\
\mathrm{POC})\end{array}$ & $\begin{array}{l}\delta^{13} \mathrm{C}_{\mathrm{CO} 2}-\varepsilon f+(\varepsilon f-\varepsilon d)^{*}\left(\mathrm{Qs}^{*} 1^{18}\right) \\
/\left(\mathrm{CO}_{2} * 1000\right) *\left((\mathrm{r} / 1000000) / \mathrm{D}_{\mathrm{T}}+1 / \mathrm{P}\right)\end{array}$ & $\%$ \\
\hline Uptake fractionation $\left(\varepsilon_{\mathrm{p}}\right)$ & $\delta^{13} C_{\mathrm{CO} 2}-\delta^{13} C_{\text {POC }}$ & $\%$ \\
\hline
\end{tabular}

And a link to the MATLAB code for the model:

https://github.com/mvdh7/miscellanea/blob/master/g40s isotopes/rau1996.m 